of the British Council in Brazil, F. M. Beatty, who lectured on British scientific travellers in the north and north-east of Brazil. Some 136 scientists and others attended this year's meeting. The programme included about 160 papers, mainly on biological subjects. Local scientists contributed especially to the sessions on nutrition in the north-east of Brazil and on mycology. In addition, special symposia were held on spot tests, experimental psychology and education, enzyme activity and, of more general interest, on "Science and Humanism". A memorial lecture on Einstein was given by Prof. Mario Schenberg, of the University of São Paulo. The principal functions were attended by Dr. Gilberto Freire, the well-known Brazilian sociologist.

The meeting was pleased to hear the message, read before one of the lectures, bearing fraternal greetings from the British Association for the Advancement of Science. The next meeting is planned to take place in Ouro Preto (Minas Gerais) in July 1956.

\section{PROBLEM OF REWARDING RESPONSIBILITY}

TN the past twelve months much has been heard of 1 the skill differential between craftsmen and labourers; for example, engineering tradesmen and labourers; building tradesmen and labourers; and, more recently, footplatemen and other railway workers. Less easy to define, though just as pertinent a problem, is the wage relationship in many manufacturing industries between various categories of unskilled or semi-skilled process workers. There is also the problem of wage relations between workpeople paid by results and those paid by time-rates for whom no opportunity to earn incentive bonus has been provided. There are, of course, many other differentials, such as those based on sex and age, time and place. Differentials are sometimes as potent a source of friction in industrial relations as the question of the wage-level itself; their effects have been elaborated by G. R. Moxon and H. J. Perkin (Personnel Management, 37, No. 332 ; June 1955).

Before 1914 the rates of pay for unskilled workers were 50-65 per cent of those for apprenticed craftsmen ; to-day they are nearer 80 per cent. The pace at which differentials have narrowed has accelerated since the War. The trend is accounted for by the bargaining strength of trade unions, particularly among the less skilled, in conditions of labour shortage and, latterly, very full employment; by the social conscience of what constitutes a fair minimum time-rate of wages; by social insurance and by acceptance of the wider application of the principles and practice of collective bargaining, conciliation and arbitration. The practice of giving the same general wage increase to all grades is the most obvious postwar feature of the drive towards a more egalitarian distribution of the national product.

Yet, difficult as is this problem of differentials, it is doubtful whether it can compete in complexity, obscurity or long-term significance for the well-being of industry, with the problem raised by the narrowing of another group of differentials, those based on responsibility. It is substantially true that the premium paid to those who direct, organize and supervise the work of others has dwindled as fast as the premium paid to skill.
This is not a problem peculiar to industry ; it is found wherever responsibility is exercised: in the Civil Service, banks, local government and, probably, most professions, and is part of the general trend towards greater equality between traditionally middleclass and working-class occupations. Indeed, the problem may well be more acute autside industry than it is inside, where the employer can more readily assess and determine fair differentials to be paid for various positions of responsibility.

In their article, Moxon and Perkin explore the social and economic setting in which the problem has come about, and discuss some of the factors which give it its peculiarly intractable shape.

Their discussion is chiefly concerned with middle and junior management-overseers, foremen, departmental managers and technical assistants, whose training demands that they should exercise leadership, organize work, use and keep abreast of modern management, methods and controls, but whose living standards are being overtaken from below.

The problem is obscure because information about salaries is not available except under privilege. The problem is complex because it is by no means confined to the comparative size of the pay-packet. That it also includes questions of status, privilege, job security and pension rights-in all of which there has been a narrowing of the traditionally held differential -is obvious.

The background to the problem is formed by the social revolution of the past half-century. Fifty years ago society was a tall pyramid with many steps. A small group at the top was very rich, and a somewhat larger group very comfortably off : together, this top 1 per cent of income eamers received nearly 30 per cent of the nation's income. At the bottom about a third of working-class families lived below the poverty line.

Fifty years of revolutionary reform have changed all that. Graduated taxation has levelled down the incomes, and, to a smaller extent, the capital of the rich. At the same time, social services and the remarkably rapid rise of the lower-paid worker have practically abolished poverty.

This means that the great majority of family incomes fall, after tax, within a narrow range of annual income-say, from $£ 300$ to $£ 2,000$. There is thus much room for differential awards. While the real earnings of almost all manual workers have risen (though skilled and adult male earnings less than unskilled, women's and juveniles'), salaries in real terms have in most cases been reduced.

At the same time, alongside the growth of the Welfare State, the trend towards greater equality of security and amenity has been reinforced by developments within the factory itself. Shorter hours, the five-day week, paid and longer holidays, canteen facilities, and the growing implementation of pension schemes, are extending to the manual worker a share of the privileges once exclusive to staff.

This measure of equality greatly aggravates the problem of rewarding responsibility. In many cases, middle and junior managers know that at least some of the workers they supervise enjoy a standard of living higher than their own.

The paradox is due to arbitrary differences in family circumstances, operating within a smaller net income range. First, the number of earners in the family, especially since the earnings of women and juveniles have increased, can make a significant 
difference. In general, the higher the status, the less likely is it that wife or children will contribute to the family budget.

Secondly, in spite of family allowance, tax reliefs and social services, commitments vary disproportionately from family to family. It is traditional for the salary earner to maintain standards of dress and spending appropriate to his status. His expenditure on other commitments, notably housing and possibly education, will be greater than the wage-earner's.

The problem of differentials in industry is substantially the same problem as that faced by society as a whole: how to share out inadequate resources between the various claimants. More specifically, it is a problem of two competing demands : the demand for fair shares and the demand for incentives for skill, initiative, ingenuity and responsibility.

To such problems there is no perfect solution. Any system of rewards must of necessity be a compromise-a reconciliation of incompatible claims. The compromise should provide a reasonably satisfactory reward for those who, inside and outside industry, carry the responsibility for upholding and extending our standards of life. This problem of rewards for responsibility is less critical and less explosive than that of differentials due to skill. The skill differential compels attention because its holders are organized and can use the force of a pressure group to publicize their grievances and gain their ends. No such relief is open to responsibilityholders.

Nor can they hope for a reversal of the social revolution which has aggravated the narrowing of their differentials. It is most improbable that there will be any return to the inequalities of pre-war days. For the narrowing of differentials there is no remedy but acceptance.

There are a number of factors helping to predispose responsibility-holders to accept a reasonable narrowing of differentials. First, the rewards of responsibility are not limited to material benefits, in cash or in kind. There are satisfactions to be gained from the exercise of responsibility itself : from a sense of doing a worth-while job. The Americans, but not the British, have inculcated that feeling into their industrial management at all levels.

Secondly, differences in monetary reward matter less once basic provision is secured for the major needs of life. The hardships experienced by some salary earners are, on the long view, comparative only, and take on an unreal appearance when set beside the poverty the social revolution set out to cure.

Thirdly, many of the responsibility-holders of to-day have risen, often via State-aided education, from lower down the social scale. They are less conscious of a traditional standard of living that they must maintain.

If the narrowing continues, what are the dangers which may result from it ? There are two which are of real concern. One is that discontent may develop to the point where recruitment to positions of responsibility falls off and shortages occur; this appears to be the case with science teachers and with dentists. The other is that discontent will sap initiative and result in an immersion in unprogressive routine. Either, if it became widespread in industrial management, might make all the difference between a rising rate of productivity and a falling one.

The great enemy of all differentials is inflation. The pay-packet of the wage earner, especially the less skilled, has on the whole kept ahead of prices. Inflation seems to have become an instrument for re-allocating the national income in favour of those with the biggest bargaining power. Worse than its effect on the immediate purchasing power of salaries is its effect on savings and pension funds.

A stabilization of prices is extremely desirable; but it demands a self-restraint on the part of organized labour on which it would be unrealistic to rely. Many firms are already countering the narrowing responsibility differential by reviewing and reassessing staff salaries whenever now wage settlements are made. It would be an act of prudence and justice if all followed the lead of the best. Though the problem has not reached the proportions of a crisis, no one can view with equanimity any further narrowing of the differential based on responsibility.

There are no quick solutions to the problem of rewarding responsibility. It is a matter for patient, long-term bargaining and readjustment.

\section{ATMOSPHERIC POLLEN}

A. HYDE (Proc. Linn. Soc., 165, 2, 107; I. 1955) has contributed new observations on the frequency of occurrence of pollen in the atmosphere which seem likely to be of interest to other investi. gators, including students of floral biology and quaternary botany, plant breeders, and members of the medical profession who are concerned with the problems of pollen allergy. The gravity slide method was used in making this pollen census. In the course of some ten years work, and making use of twelve different collecting stations, it has been possible to determine about 90 per cent of all the grains on the slides and to assign these to one or other of sixty-five different types.

The principal pollen types, listed in the order of their numerical importance, begin with the Gramineae with $48 \cdot 3$ per cent, followed by Ulmus with $11 \cdot 6$ per cent, Quercus 8.2 per cent, and so on down to Ranunculus with 0.41 per cent, and the sedges with 0.22 per cent. Variations in the pollen catch and in the preponderance of the different types from year to year in relation to weather conditions are considered and some interesting conclusions drawn. These are but indications of the several records presented and discussed.

On the subject of hay-fever, the author writes : "No kind of pollen is likely to evoke symptoms in a significant number of people unless it is formed and liberated in large quantities and is buoyant (so becoming and remaining airborne) and unless the source plant is widely and abundantly distributed. The results of the Cardiff pollen census, when considered in the light of this principle, show that the chief hay-fever plants of Great Britain are relatively few in number, viz., the grasses considered as a single group (since all kinds of grass pollen are generally assumed to be similarly antigenic), certain trees, viz., the oaks, ash, the elms and plane (notably in London), and certain herbs, viz., the plantains, docks and sorrels, and possibly common nettle. It is necessary before forming a diagnosis on a particular patient's hay-fever to be able to show that his symptoms coincided with or at least fell within the period during which he was actually inhaling the pollen concerned. For this purpose reference to the frequency diagrams is essential." 